
www.globaljournalseries.com; Email: info@globaljournalseries.com

\title{
EFFECT OF DIFFERENT SIZES OF PLANTING MATERIAL ON THE GROWTH AND YIELD COMPONENTS OF EDIBLE MUSHROOM PLEUROTUS TUBERREGIUM
}

I. O. UDO AND E. A. AKPAN

(Received 30, June 2011; Revision Accepted 30, March 2012)

\begin{abstract}
An experiment was conducted in 2004 and 2005 at the University of Uyo Teaching and Research Farm to assess the effect of different weights of planting materials on the performance and yield components of edible mushroom Pleurotus tuberregium. The experiment was laid out in Randomized complete block design with three weights $(20 \mathrm{~g}, 40 \mathrm{~g}$ and $60 \mathrm{~g})$ as treatments and replicated five times. Each plot size measured $1 \mathrm{~m} \times 1 \mathrm{~m}$ with a total of 16 polybags per plot. Parameters studied were percent emergence, cap diameter, stipe height and girth as well as number of shoots. Results obtained showed no significance $(P<0.05)$ in percent emergence amongst the weights of planting materials. However, a significant $(P<0.05)$ effect was recorded in cap diameter $(3.68 \mathrm{~cm})$ from the $20 \mathrm{~g}$ weight planting material. Stipe height and girth did not show any significant difference amongst the treatments. The $60 \mathrm{~g}$ planting material weight recorded more shoots than the $20 \mathrm{~g}$ and $40 \mathrm{~g}$ planting material sizes. The $60 \mathrm{~g}$ planting material weight is recommended to farmers for the purpose of multiplication of Pleurotus tuberregium for better economic returns.
\end{abstract}

KEY WORDS: Stipe, Cap Diameter, Edible Mushroom, Percent Emergence, Weight.

\section{INTRODUCTION}

Pleurotus mushroom is generally called the oyster mushroom because the pileus or cap is shell-like, spatulate and the stipe is eccentric or lateral (Oei, 1991). More than 1,000 species of oyster mushroom have been described in more than 25 related genera throughout the world (Wasser, 2002). According to Guzman (2000), approximately 50 valid species are recognized in the genus Pleurotus with the commonly cultivated species including $P$. sajor-caju (Frics) Sing. which is also referred to as gray oyster or phoenix-tail mushroom, $P$. cystidiosus, Miller otherwise called abalone mushroom, $P$. ostreatus var. Florida nom. Eger also called white oyster mushroom, P. flabellatus (Berk. and Br.) Sacc which is known as Pink oyster mushroom and $P$. sapidus (Schulzer) Kalchbremer. Pleurotus is a saprophyte capable of degrading already dead material and need organic matter to decompose. This explains why in natural habitat they thrive on fallen leaves, animal droppings and stumps of wood (Chang and Mshigeni, 2004).

Mushroom is a seasonal delicacy in Nigeria and other parts of the world, they start appearing between the months of March to April during the beginning of the rainy season. Mushroom cultivation requires little labour, investment and space but the return on investment is usually very high. The economic importance of mushroom in terms of nutritional value shows they contain $21-40 \%$ protein comparable with soybeans and peas. They have low sugar and fat content but are richer in essential vitamins (Oei, 1991). Mushrooms have been reported to boost the immune system, lower cholesterol, function as an anticoagulant and may have use in treatment of some cancers (Wasser, 2002, Ashrafuzzaman et al., 2009). Propagation and cultivation of mushrooms often become difficult arising from the procurement of sclerotia as planting material.

This may be as a result of poor preservation of sclerotia and harsh environmental conditions which could affect the germination potential of the sclerotia when planted. It therefore becomes imperative that planting materials of sclerotia should be well managed in order to achieve economical mushroom production. In view of the enormous potentials and importance of mushroom, an experiment was conducted to determine the suitable planting sizes of sclerotia that would aid commercial mushroom production and boost other growth parameters.

\section{Materials and Methods}

\section{Procurement of Sclerotia and Cultivation}

The planting material of $P$. tuberregium which is the sclerotia was obtained from Uyo main market in Nigeria. The materials were allowed to dry under shade for 24 hours in order to reduce the moisture content. The sclerotia were cut using matchet into three planting sizes of $20 \mathrm{~g}, 40 \mathrm{~g}$ and $60 \mathrm{~g}$. The various sizes were determined by weighing using a chemical weighing balance.

I. O. Udo, Department of Crop Science, University of Uyo, PMB1017, Uyo, Nigeria

E. A. Akpan, Department of Crop Science, Akwa Ibom State University Obio Akpa Campus, Akwa Ibom State, Nigeria 


\section{Planting}

The various sizes of sclerotia were planted in polybags that were filled with top soil. The experiment was laid out in the open field in a complete randomized block design. There were five replications of the three treatments with a total of 16 polybags per plot with the plot size being $1 \mathrm{~m} \times 1 \mathrm{~m}$. Watering of the planting materials was carried out for five days. Data collected were percentage emergence, number of shoots, stipe height measured in centimeter using a meter rule. The girth and cap diameter were measured in centimeter by running a thin thread round them and then measured using a meter rule.

\section{Data analysis}

All data generated were subjected to analysis of variance while means were separated using least significant difference.

\section{RESULTS AND DISCUSSION}

The percentage emergence of the different sizes of sclerotia for the first and second planting seasons is shown in Tables $1 a$ and $b$. There was no significant difference amongst the different sizes in terms of emergence during the two seasons. This could be as a result of the fact that the planting materials were subjected to the same growth medium and environmental conditions. This has been reported earlier (Ezeh, 1994) that given the same environmental conditions, $P$. tuberegium will sprout within 3 days as was observed in the present study. The apparent non significance in terms of percentage emergence is indicative of the fact that even the $20 \mathrm{~g}$ size of sclerotia favours the rapid multiplication and propagation of $P$. tuberregium for higher returns on investment and profit maximization.

Stipe height was not significant in the first planting season but during the second planting season, the $20 \mathrm{~g}$ size produced the highest stipe height (Table $1 \mathrm{a}$ and $b$ ). This could be due to the larger sizes of sclerotia $(40 \mathrm{~g}$ and $60 \mathrm{~g})$ which had a higher accumulation of food materials which encouraged the production of stout stipes as reflected in the stipe girth (Chang and Mshigeni, 2004).

Results for stipe girth, number of shoots and cap diameter for the first and second planting seasons are summarized in Table $1 a$ and $b$. number of shoots was significantly $(P<0.05)$ affected by planting material sizes while the cap diameter showed no significant difference between the different planting sizes of sclerotia. From the results obtained, the performance of the different planting sizes of $P$. tuberregium indicates that there is no use wasting sclerotia by planting larger sizes while as small as $20 \mathrm{~g}$ planting size could still result in profitable cultivation of $P$. tuberregium (Ashrafuzzaman et al., 2009; Nweke et al, 1991; Chang and Miles, 2004). Farmers and investors in $P$. tuberregium should be encouraged to use small size of $20 \mathrm{~g}$ sclerotia for better performance in terms of emergence, stipe height and girth, number of shoots and cap diameter, thus minimizing cost of planting materials and maximizing profit.

Table 1a: Effect of different planting material sizes on $P$. tuberregium growth (2004 season)

\begin{tabular}{lccccc}
\hline $\begin{array}{l}\text { Planting } \\
\text { size }(\mathrm{g})\end{array}$ & \% emergence & $\begin{array}{l}\text { Growth parameters } \\
\text { Stipe } \\
\text { height }(\mathrm{cm})\end{array}$ & $\begin{array}{l}\text { Stipe } \\
\text { girth }(\mathrm{cm})\end{array}$ & $\begin{array}{l}\text { Number } \\
\text { of shoots }\end{array}$ & $\begin{array}{l}\text { Cap } \\
\text { diameter }(\mathrm{cm})\end{array}$ \\
\hline 20 & $63.88 \pm 4.16$ & $2.69 \pm 0.30$ & $2.06 \pm 0.36$ & $2.07 \pm 0.26$ & $2.29 \pm 0.39$ \\
40 & $62.50 \pm 5.13$ & $2.60 \pm 0.36$ & $3.14 \pm 0.32$ & $2.15 \pm 0.31$ & $2.18 \pm 0.32$ \\
60 & $63.19 \pm 4.82$ & $2.56 \pm 0.33$ & $3.77 \pm 0.54$ & $2.12 \pm 0.32$ & $2.62 \pm 0.47$ \\
Mean & $63.19 \pm 4.70$ & $2.62 \pm 0.33$ & $2.99 \pm 0.40$ & $2.11 \pm 0.29$ & $2.36 \pm 0.39$ \\
LSD & 0.89 & 0.10 & 1.01 & 0.56 & 0.38 \\
$(0.05)$ & & & & &
\end{tabular}


Table 1b: Effect of different planting material sizes on $P$. tuberregium growth (2005 season)

\begin{tabular}{lccccc}
\hline $\begin{array}{l}\text { Planting } \\
\text { size }(\mathrm{g})\end{array}$ & \% emergence & $\begin{array}{l}\text { Growth parameters } \\
\text { Stipe } \\
\text { height }(\mathrm{cm})\end{array}$ & $\begin{array}{l}\text { Stipe } \\
\text { girth }(\mathrm{cm})\end{array}$ & $\begin{array}{l}\text { Number } \\
\text { of shoots }\end{array}$ & $\begin{array}{l}\text { Cap } \\
\text { diameter }(\mathrm{cm})\end{array}$ \\
\hline 20 & $57.63 \pm 4.08$ & $5.68 \pm 1.93$ & $3.85 \pm 0.58$ & $1.36 \pm 0.24$ & $5.08 \pm 0.99$ \\
40 & $55.08 \pm 4.49$ & $3.64 \pm 0.65$ & $3.15 \pm 0.53$ & $1.44 \pm 0.28$ & $5.17 \pm 1.03$ \\
60 & $58.19 \pm 4.09$ & $3.70 \pm 0.50$ & $3.07 \pm 0.36$ & $1.58 \pm 0.26$ & $4.57 \pm 0.70$ \\
Mean & $56.93 \pm 4.22$ & $4.34 \pm 1.03$ & $3.36 \pm 0.49$ & $1.46 \pm 0.26$ & $4.94 \pm 0.90$ \\
LSD & 0.95 & 1.04 & 0.58 & 0.89 & $0.70(0.05)$ \\
\hline
\end{tabular}

\section{REFERENCES}

Ashrafuzzaman, M., Kamruzzaman, A. K. M., Razi ismail, M., Shahidullah, S. M. and Fakir, S. A., 2009. Substrate affects growth and yield of shiitake mushroom. African Journal of Biotechnology. 8(13): $2999-3006$

Chang, S. T. and Miles, P. G., 2004. Mushroom; Cultivation, Nutritional value, Medicinal Effect and Environmental Impact. $2^{\text {nd }}$ ed. CRC Press. 451.

Chang S. T. and Mshigeni, K. E., 2004. Mushrooms and Human Health: Their growing significance as potent dietary supplements. University of Namibia. 79.

Ezeh, N. O. A., 1994. Economics of seed yam production from minisetts in Umudike, Southeastern Nigeria. Proc. $9^{\text {th }}$ triennial symposium of International Society for Tropical Root Crops. 378 - 385
Guzman, G., 2000. Genus Pleurotus [Jacq.; Fr] P. Kumm. (Agaricomycetidae): Diversity, Taxonomic Problems, Cultural and Traditional Medical uses. Int. J. Med. Mushroom 2: 95 123.

Nweke, F. I., Ugwu, B. O., Asaidu, C. L. and Ay P., 1991. Production cost in the yam based cropping systems of Southeastern Nigeria. Research monograph No. 6. Resource and Crop Management Program. IITA, Ibadan, Nigeria

Oei, P., 1991. Manual on mushroom cultivation. CTA/Tool Publication, Netherlands

Wasser, S. P., 2002. Medicinal mushrooms as a source of antitumor and immuno-modulating polysaccharides. Appl. Microbiol. Biotechnol. 60: $258-274$ 